\title{
Assessing land suitability for aquifer storage and recharge in northern Ghana using remote sensing and GIS multi-criteria decision analysis technique
}

\author{
Seth Owusu ${ }^{1}$ (1) $\cdot$ Marloes L. Mul $^{1} \cdot$ Benjamin Ghansah $^{1} \cdot$ Paa Kofi Osei-Owusu $^{2}$ \\ Vincent Awotwe-Pratt ${ }^{2} \cdot$ Davie Kadyampakeni $^{3}$
}

Received: 28 July 2017 / Accepted: 4 August 2017 / Published online: 22 August 2017

(c) The Author(s) 2017. This article is an open access publication

\begin{abstract}
Increasing climate variability and challenge in access to water pose major impediments to rainfed agricultural productivity. Extensive flooding of agricultural lands during the rainy season and lack of water during the 8-month long dry season affect the livelihood of the people in the northern Ghana, a situation that calls for better water management practices. The use of aquifer storage and recharge (ASR) based technique, helps to reduce flooding and improve access to water during the dry season; however such technology has specific requirements for successful implementation. This study assesses suitable areas for the technology in the northern Ghana terrain using multi criteria decision analysis (MCDA) in ArcGIS environment. The result suggests around $66 \%\left(48,516 \mathrm{~km}^{2}\right)$ of the crop area in the northern Ghana available for the technology are within moderate to very high suitable sites, of which $44 \%$ $\left(29,490 \mathrm{~km}^{2}\right)$ fall into the high and very high suitable sites. This could imply high potential for the artificial groundwater storage system in northern Ghana given other conditions.
\end{abstract}

Keywords Northern Ghana · ASR · Irrigation ·

Bhungroo $\cdot$ Suitability $\cdot$ MCDA

\section{Introduction}

Agriculture in Sub-Saharan Africa (SSA) is facing challenges due to changing climatic conditions affecting the

Seth Owusu

owususok@yahoo.com

1 International Water Management Institute, Accra, Ghana

2 Conservation Alliance, Accra, Ghana

3 University of Florida, Lake Alfred, USA availability and distribution of water. Dryspells continue to threaten agricultural production and food security (Sasson 2012), whereas in nearly equal measures, excess water causing waterlogging and flooding potentially can destroy entire crops and return of farmer investments (Bradd et al. 1997; Singh et al. 2010; Singh 2016). The need for agricultural water management (AWM) to address challenges of water access for smallholder farming is rising, and investments in AWM is expected to change lives of millions rural people (Evans et al. 2012; Giordano et al. 2012). With Ghana's agrarian economy highly dependent on rainfed agriculture, growing vagaries in rainfall pattern pose a significant problem to sustainable agriculture and economic development. Most (60\%) of the economically active population are employed in the agricultural sector, but the prevalence of poverty is still very high in the region with the majority found in northern Ghana (Diao 2010). The impact on the national level is also substantial as the agricultural sector contributes to around $38 \%$ of the foreign exchange earnings (ISSER 2008), making this an opportune time to explore appropriate AWM solutions.

AWM interventions for water storage and conservation for agricultural use such as small reservoirs and natural ponds are options providing smallholder farmers access to water for dry season irrigation (McCartney and Smakhtin 2010; Evans et al. 2012; Giordano et al. 2012). Moreover, less than $2 \%$ of the total cultivated land in Ghana is under irrigation and shallow wells and dug-outs are the most common in areas under formal irrigation (Namara et al. 2011, 2014; Gumma et al. 2011). The challenge with surface water storage technologies is that they are affected by high evaporation losses due to high temperatures (McCartney and Smakhtin 2010). Therefore, innovative AWM solutions such as subsurface storage can help reduce waterlogging, high evaporative losses of surface water storage, and at the same 
time increase groundwater recharge (Murray and Tredoux 1998; Pyne 1995; Singh 2016).

Examples of aquifer storage and recovery (ASR) techniques are the Bhungroo and Pave Irrigation Technology (Biplab 2013; Conservation Alliance (CA) 2015). These technologies artificially recharge groundwater from waterlogged areas through the installation of an infiltration pit and borehole (Bouwer 2002; Bear 2012; Edwards et al. 2016). They employ the process of filtration through constructed infiltration bed to remove unwanted constituents before transmitting water to unsaturated aquifers for storage (Bouwer 2002; Edwards et al. 2016). Water is stored in the underlying aquifer and accessed through pumps using the same borehole (Owusu et al. 2017). Water is used during the dry season to irrigate high value crops. ASR is a proven technology, which is scaled among smallholder farmers in Gujarat state in Western India, with evidence that during the dry season the recharged groundwater is sufficient to support irrigation and other uses, thus contributing towards addressing the issue of water scarcity and food productivity (Biplab 2013; CA 2015; Bunsen and Rathod 2016). ASR techniques are therefore potentially suitable technologies to be applied in Ghana to address the issues of both waterlogging during the wet season and providing water for irrigation during the dry season while minimising evaporative losses.

ASR technique shows great potential, however it has very particular requirements to make it successful, including the surface and subsurface potential. The study assesses the suitability of the ASR techniques in northern Ghana using GIS mapping approach and multi-criteria weighting technique.

\section{Materials and methods}

\section{Study area}

The study area is the northern part of Ghana, which is made up of the Northern Region (NR), Upper East Region (UER) and Upper West Region (UWR), as marked out in Fig. 1. Although the poorest and underdeveloped of all regions in Ghana, the northern regions have about $75 \%$ of the active population engaged in food crop production, and the major land use is cultivated savannah woodland covering almost $60 \%$ of the total land area (HAP 2011). The region is characterized by high temperature from 27 to $29^{\circ} \mathrm{C}$ with extreme range of $17-40^{\circ} \mathrm{C}$, and a seasonal rainfall distribution from May to October (HAP 2011). The annual rainfall ranges from 800 to $1300 \mathrm{~mm}$ year $^{-1}$ while annual potential evapotranspiration ranges from 987 to $1192 \mathrm{~mm} \mathrm{year}^{-1}$ (HAP 2011). The study area is also characterized by severe seasonal flooding, especially low-lying areas along the Black and White Volta Rivers and their tributaries where floods have resulted in life lost, destruction to farmlands and crop yields (UNDP 2009; Mul et al. 2015). Two main geological formations exist in the area, the basement crystalline rocks (Precambrian) which underlie $41 \%$ of the area and the Paleozoic sedimentary rocks (Voltaian) (GGS 2009). Groundwater availability in these two main environments is highly variable due to the weathering process, which also influences the storage capacity of rocks (Dapaah-Siakwan and Gyau-Boakye 2000; Forkuor et al. 2013). Productive aquifer zone ranges from 10 to $60 \mathrm{~m}$ and most successful

Fig. 1 Map of northern Ghana

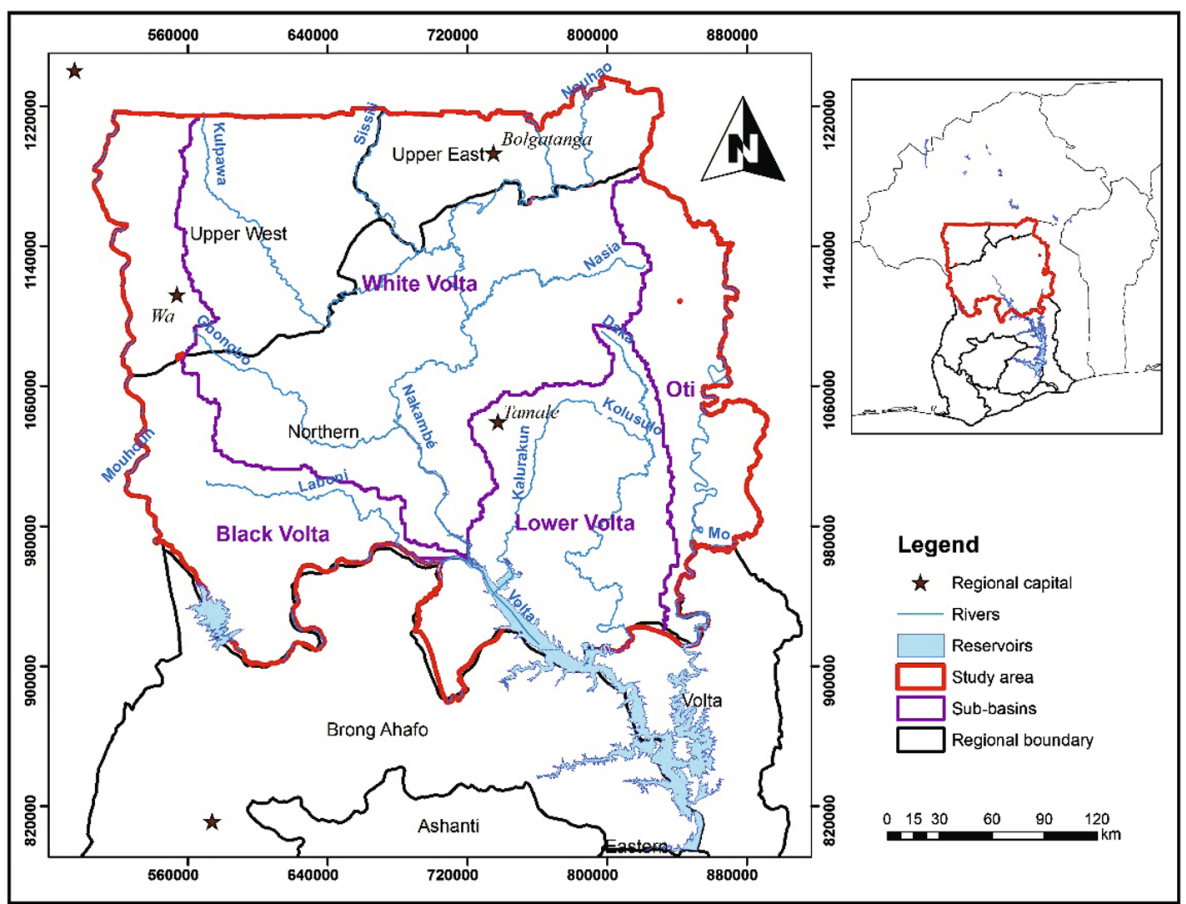


boreholes in northern Ghana are often less than $80 \mathrm{~m}$ deep (Obuobie and Barry 2012).

\section{Suitability mapping}

The success of ASR technology is dependent on various factors, which were grouped under: (1) surface conditions that facilitate the occurrence of flood-prone areas, (2) subsurface conditions focus on the storage capabilities of the underground and (3) socio-economic conditions (Murray 2008; Bunsen and Rathod 2016).

Each factor under the criteria was reclassified into appropriate classes in GIS environment mostly using Jenks Natural Breaks or natural groupings inherent in the data (de Smith et al. 2015). The classes were then standardized using a common scale of $0-5$ (where $0=$ no importance/ restricted, $1=$ very low suitability, $5=$ very high suitability). Standardization helps to convert each criteria map to a uniform measurement scale so that they are easily comparable (Yalew et al. 2016).

\section{Surface criteria}

The factors assessed here were: landcover, slope, soil and surface water accumulation. The land use data obtained from previous study by Mul et al. (2015) was reclassified with respect to the dominant land cover features in the study area. Cultivated savannah covering $55 \%$ of the total area was ranked 5 while natural land cover classes were least preferred sites, whereby riverine was ranked with low value of "2" because of high sediment loads in the rivers and high variations in water levels, potentially submerging the access tube. Waterbody was ranked " 0 ", meaning they were restricted and had no influence on the overall analysis (Fig. 2a; Table 1). Additional data on restricted areas were included, national parks were digitized from Google

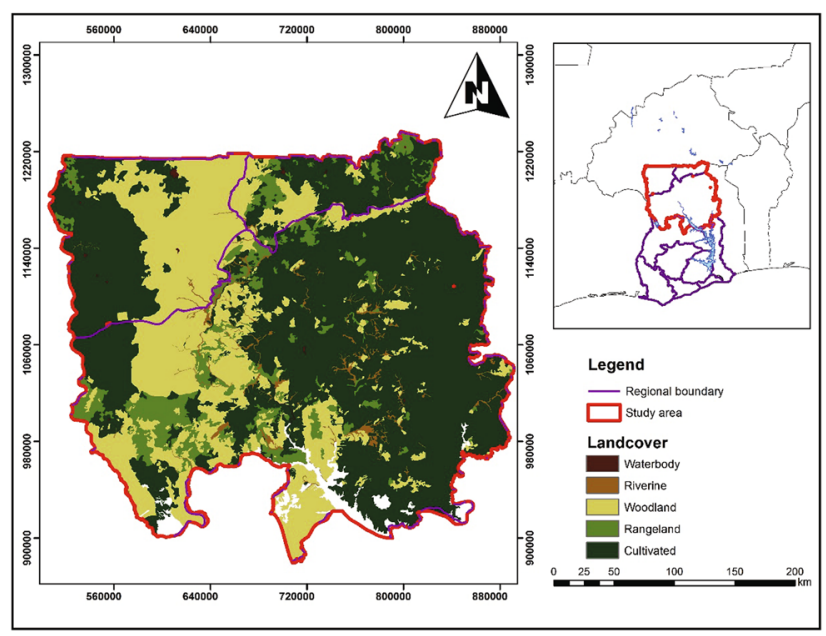

(a) Landcover of northern Ghana (source data: Mul et al 2015)

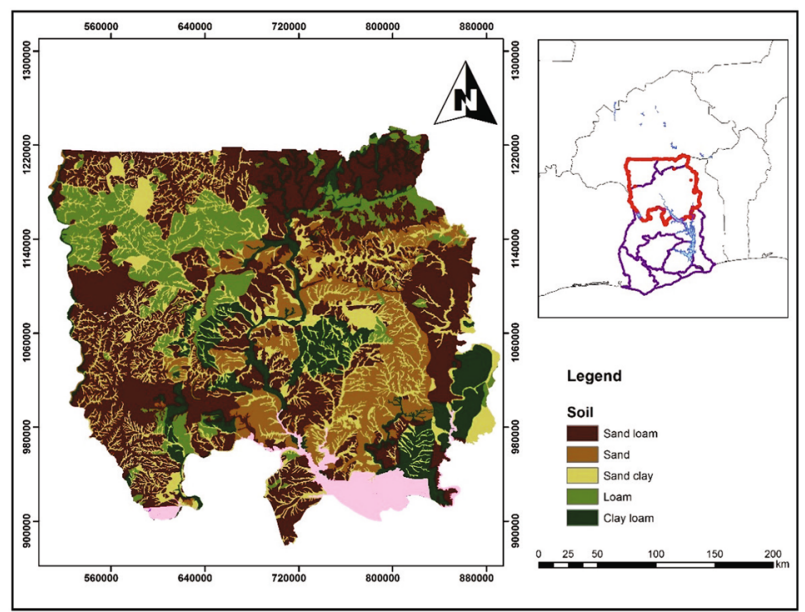

(c) Soil texture class of northern Ghana (source data: FAO-IIASA-ISRIC-ISS-CAS-JRC 2012)

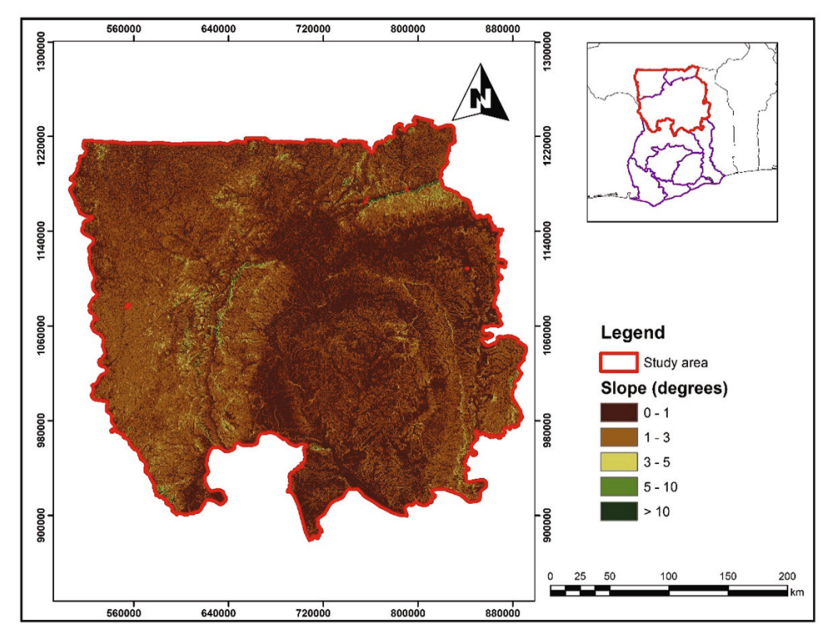

(b) Slope of northern Ghana (source data: LP DAAC 2016)

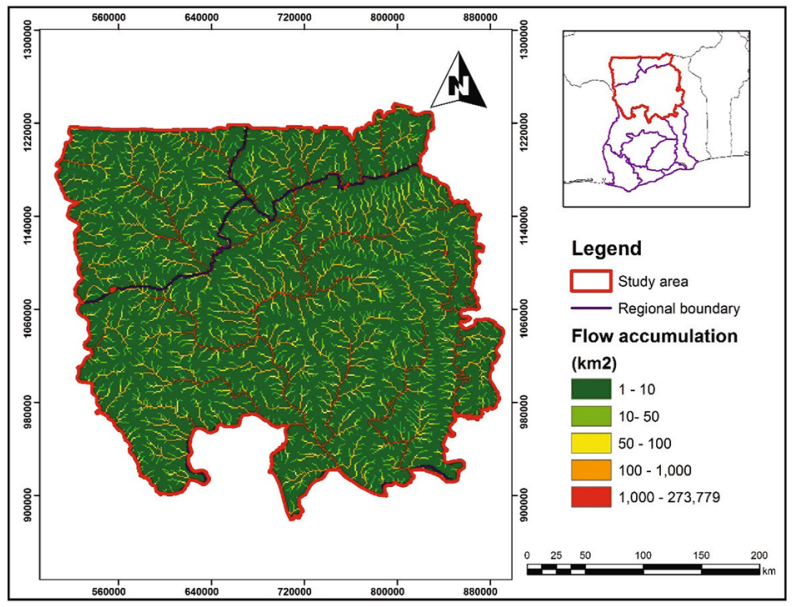

(d) Flow accumulation of northern Ghana (source data: EROS 2016)

Fig. 2 Reclassified surface criteria: a land cover, $\mathbf{b}$ slope, $\mathbf{c}$ soil, $\mathbf{d}$ flow accumulation of northern Ghana 
Table 1 Classification of surface criteria

\begin{tabular}{llclllllr}
\hline Suitability score & Land cover & Area $(\%)$ & Slope & Area $(\%)$ & Soil & Area (\%) & Flow accumulation & Area $(\%)$ \\
\hline 0 (restricted) & Waterbody & 0.13 & & & & & & \\
1 & & & $>10$ & 0.25 & Sand-loam & 42.18 & $>1000$ & 2.51 \\
2 & Riverine & 1.86 & $5-10$ & 0.64 & Sand & 12.36 & $1-10$ & 82.65 \\
3 & Woodland & 35.09 & $3-5$ & 1.95 & Sand-clay & 20.33 & $10-50$ & 8.58 \\
4 & Rangeland & 7.59 & $1-3$ & 45.46 & Loam & 13.31 & $50-100$ & 2.40 \\
5 & Cultivated & 55.33 & $0-1$ & 51.70 & Clay-loam & 11.83 & $100-1000$ & 3.86 \\
\hline
\end{tabular}

Earth (Google Earth 2015) while the flood plain areas were identified using the height above nearest drainage (HAND) approach and validated against field observations and satellite data (Nobre et al. 2016; Balana et al. 2015).

Slope was analysed using digital elevation model (DEM) with a resolution of $90 \mathrm{~m}$ obtained from United States Geological Survey (USGS) (LP DAAC 2016). The slope map shows that northern Ghana is a generally flat, with $99 \%$ of the area having average slope of $0^{\circ}-5^{\circ}$ (Fig. 2b; Table 1). A rank of five was given to a slope range of $0^{\circ}-1^{\circ}$ which formed $52 \%$ of the area, while slope greater than $10^{\circ}$ was ranked 1 and hence less suitable.

The soil data was obtained from FAO-IIASA-ISRICISS-CAS-JRC (2012) with a $250 \mathrm{~m}$ resolution raster. This was reclassified and ranked based on the capacity to retain water and susceptibility to flooding, as depicted in Fig. 2c and Table 1. Clay-loam soil was ranked 5 and sand-loam which covered larger land area (42\%) than all soil types was the least suitable option because of the low water holding capacity and available water content (Obuobie 2008; Balana et al. 2015).

The probability of flooding from upstream was used as an indicator of flood proneness of the study area. A flow accumulation network was developed using DEM, whereby the flow for each pixel was computed and the upstream accumulation was determined (Jenson and Domingue 1988). The resulting raster layer provides information on areas with high or low probability of flooding (Fig. 2d). The high probability areas $\left(>1000 \mathrm{~km}^{2}\right)$ are mainly the river channels which were marked as less suitable due to problems associated with using water directly from the floodplains, while the highest rank (5) was for the range of $100-1000 \mathrm{~km}^{2}$ for more preferable areas.

\section{Subsurface criteria}

Subsurface criteria determines the underground storage capacity, which requires that the underground aquifer consist of a medium which has good storage, both in terms of the porosity as well as the depth of the formation (Hofkes and Visscher 1986; Murray 2008). The geological indicators (transmissivity and regolith thickness) were derived from geological maps developed by Ghana Geological Survey Department in 2009 (GGS 2009; HAP 2011). Maps containing data on the hydrogeology (static water level, borehole success rate) were obtained from Forkuor et al. (2013), based on the borehole databased developed by the Water Resources Commission (HAP 2011).

The transmissivity in the area ranges from 3 to $26 \mathrm{~m}^{2}$ day $^{-1}$, with higher values showing more productive borehole and less drawdown. The majority of the study area fall within 3-12 $\mathrm{m}^{2} \mathrm{day}^{-1}$, which was ranked low (Fig. 3a; Table 2). The regolith thickness determined from 800 boreholes (Forkuor et al. 2013) showed a minimum range of 4-12 m which was ranked the least while the highest ranked was for the range 33-39 $\mathrm{m}$ (Fig. 3b; Table 2). Static water level was based on 878 boreholes (Forkuor et al. 2013) and ranged from 0 to $10 \mathrm{~m}$ to $>100 \mathrm{~m}$. A range of $30-70 \mathrm{~m}$ depth of borehole is most suitable for the ASR technique (UNFCCC 2014), and from the results majority of the area has static water level from 10 to $70 \mathrm{~m}$, which implies high potential for the study area. The percentage of borehole success rates shown in Fig. 3c and Table 2 was based on 8447 boreholes across the study area and using a threshold of $101 \mathrm{~min}^{-1}$ as a minimum standard yield for successful rate (CWSA 2010; Forkuor et al. 2013).

\section{Socio-economic criteria}

Proximity to major roads was used as an indicator for access to market. Road data covering actual size of the road networks was obtained from SADA (2006) and reclassified following a buffer operation (Fig. 4a). Range 0-100 m representing $2 \%$ of the total area was marked as unfavourable, while the remaining classes were apportioned ranks from " 2 " to " 5 " with the farther distance $(>20,000 \mathrm{~m})$ being less favourable for the technology, as shown in Table 3.

Population density was also used as criteria for site suitability, where areas with lower population density were deemed more suitable as the ASR are very local scale technologies supporting at most 50 farmers (Biplab 2013). The population density data with a resolution of $90 \mathrm{~m}$ was obtained from the Socioeconomic Data and Applications 


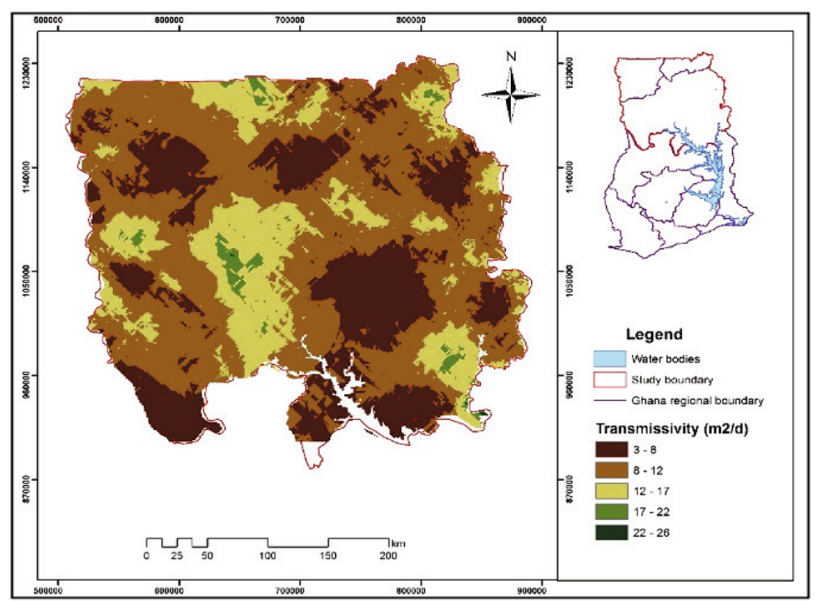

(a) Transmissivity range of northern Ghana (source data: Forkuor et al. 2013)

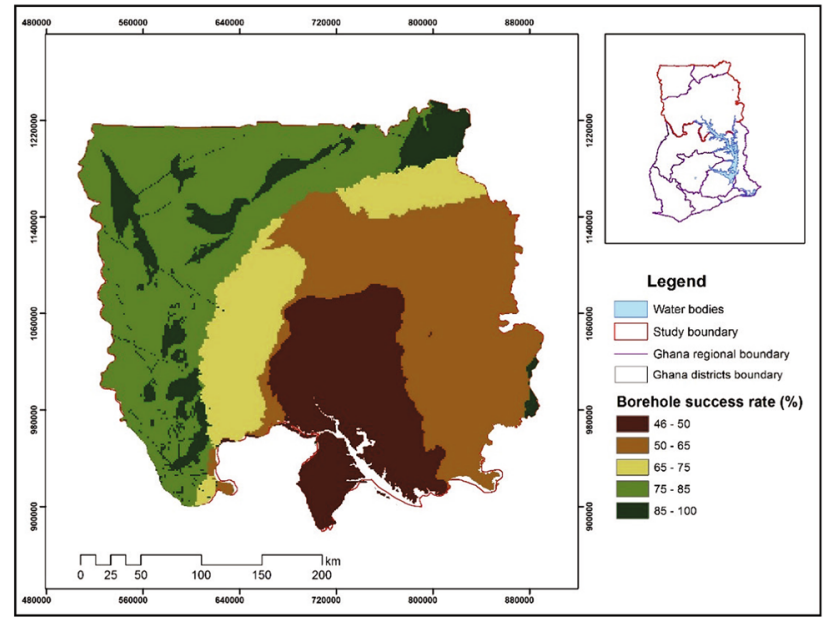

(c) Borehole success rate for northern Ghana (source data Forkuor et al. 2013)

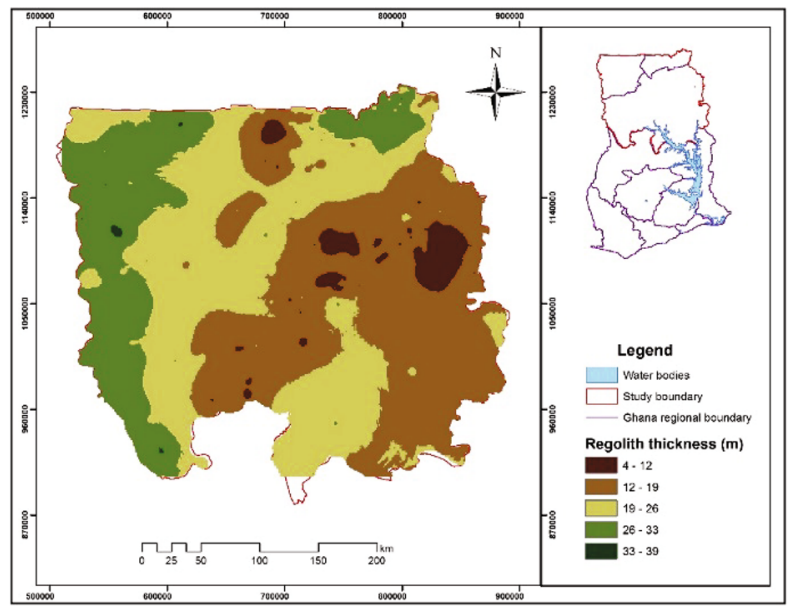

(b) Regolith thickness of northern Ghana (source data Forkuor et al. 2013)

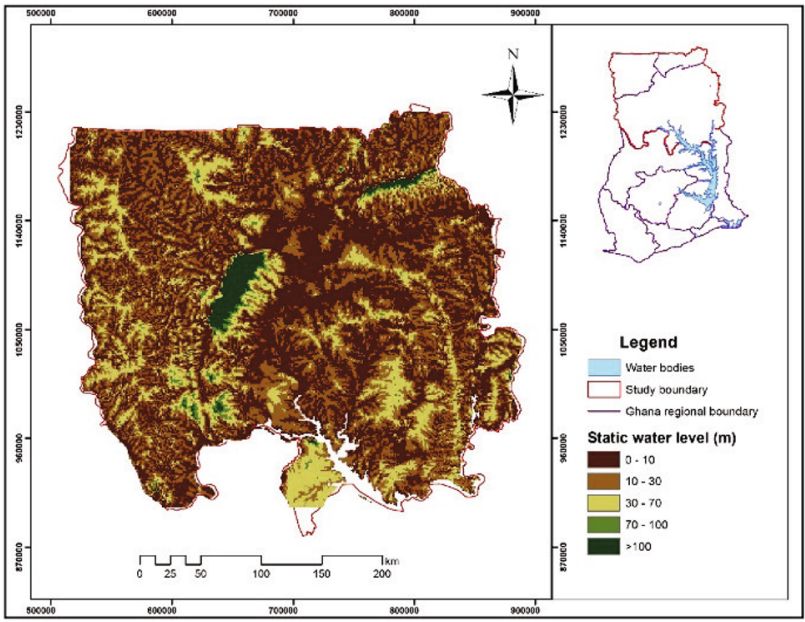

(d) Static water level of northern Ghana (source data: Forkuor et al. 2013)

Fig. 3 Reclassified subsurface criteria: a transmissivity, b regolith thickness, c borehole success rate, $\mathbf{d}$ static water level of northern Ghana (Forkuor et al. 2013)

Table 2 Reclassified subsurface criteria

\begin{tabular}{llllclclc}
\hline $\begin{array}{l}\text { Suit- } \\
\text { ability } \\
\text { score }\end{array}$ & $\begin{array}{l}\text { Transmis- } \\
\text { sivity } \\
\left(\mathrm{m}^{2} \text { day }^{-1}\right)\end{array}$ & Area (\%) & $\begin{array}{l}\text { Regolith } \\
\text { thickness } \\
(\mathrm{m})\end{array}$ & Area (\%) & $\begin{array}{l}\text { Borehole } \\
\text { success } \\
(\%)\end{array}$ & Area (\%) & $\begin{array}{l}\text { Static } \\
\text { water level } \\
(\mathrm{m})\end{array}$ & Area (\%) \\
\hline 1 & $3-8$ & 25.98 & $4-12$ & 2.76 & $<50$ & 17.82 & $0-10$ & 82.10 \\
2 & $8-12$ & 57.75 & $12-19$ & 34.94 & $50-65$ & 28.77 & $>100$ & 15.02 \\
3 & $12-17$ & 15.13 & $19-26$ & 39.20 & $65-75$ & 13.20 & $70-100$ & 1.09 \\
4 & $17-22$ & 1.11 & $26-33$ & 22.81 & $75-85$ & 31.69 & $10-30$ & 1.33 \\
5 & $22-26$ & 0.03 & $33-39$ & 0.29 & $85-100$ & 8.51 & $30-70$ & 0.47 \\
\hline
\end{tabular}

Center (SEDAC) (Balk et al. 2006). The reclassified and ranked data are shown in Fig. $4 \mathrm{~b}$ and Table 3.

\section{Analytical hierarchical process}

Analytical hierarchical process (AHP) provides a framework for decision-making process and it is well-established integrated GIS-based MCDA used in spatial analysis (Yalew et al. 2016). AHP provides a means of assigning weights to the different criteria and has been used for various land suitability assessments, from watershed planning to agricultural land use (Bandyopadhyay et al. 2009; Motuma et al. 2016; Yalew et al. 2016). 
Fig. 4 Reclassified socio-economic criteria a road network $\mathbf{b}$ population density of northern Ghana

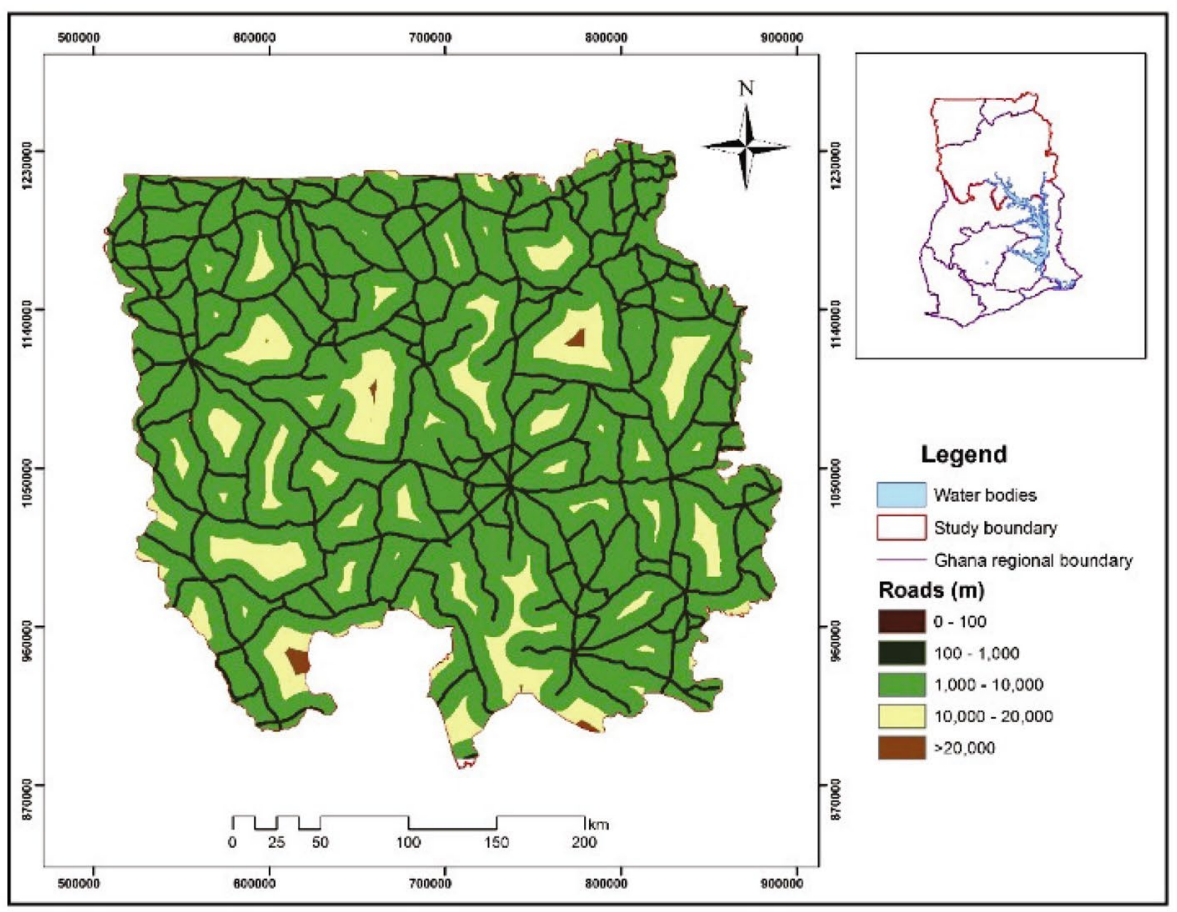

(a) Distances to road (source data: SADA 2006)

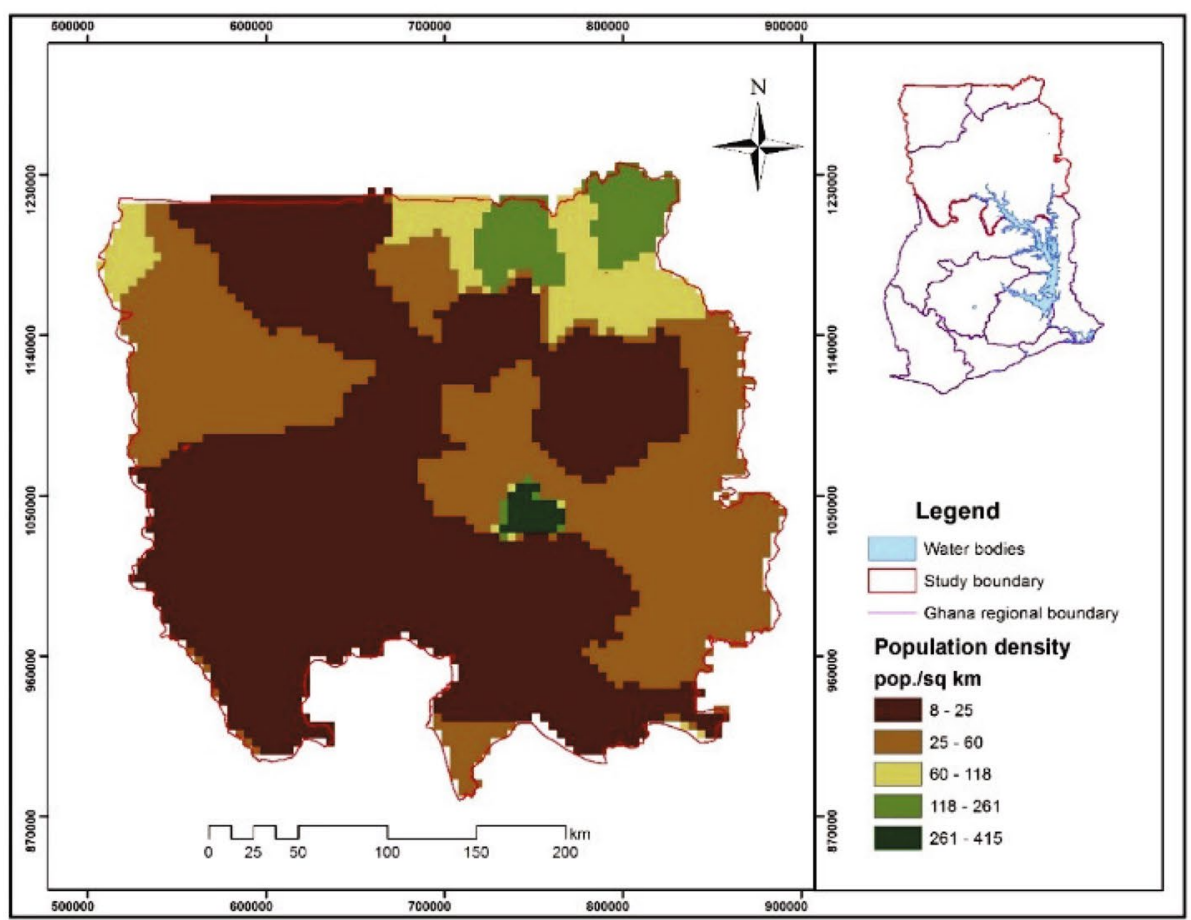

(b) Population density (source data: Balk et al. 2016)
AHP was used in this study to calculate weights for the reclassified and standardised criteria, by first developing a pairwise comparison matrix based on Saaty (1980) guideline, using a numerical scale of 1-9 to establish the relative importance of the criteria (Saaty 2008). The pairwise matrix produced for the study is presented in Table 4 showing the relative importance of each criterion.

The weights computed using the AHP approach are comparative weights of individual criterion, in reference to their determined ranks. Computing the consistency ratio $(C R)$ 
Table 3 Percentage of total area covered by socio-economic criteria

\begin{tabular}{llclc}
\hline $\begin{array}{l}\text { Suit- } \\
\text { ability } \\
\text { score }\end{array}$ & Distance to roads (m) & Area (\%) & $\begin{array}{l}\text { Population } \\
\text { density } \\
\left(\mathrm{km}^{-2}\right)\end{array}$ & Area (\%) \\
\hline 0 & $0-100$ & 2.46 & & \\
1 & & & $8-25$ & 4.94 \\
2 & $>20,000$ & 0.29 & $25-60$ & 10.83 \\
3 & $10,000-20,000$ & 10.47 & $60-118$ & 24.43 \\
4 & $1000-10,000$ & 73.33 & $118-261$ & 24.95 \\
5 & $100-1000$ & 13.45 & $261-415$ & 34.85 \\
\hline
\end{tabular}

using Eq. 1 helps to identify and correct the logical inconsistency of the pairwise comparison matrix developed based on experience or expert judgement. Where the $C R$ value is more than 0.1 the judgement could be said to be unreliable as they may be too close to randomness and thus need modification (Saaty 1988; Lee and Chan 2008; Yalew et al. 2016). Equation 2 gives the consistency index $(C I)$ which forms an input for determining the $C R$.

$C R=\frac{C I}{R I}$,

where $C I$ represents consistency index, $R I$ represents random index.

$C I=\frac{\left(\lambda_{\max }-\mathrm{n}\right)}{(\mathrm{n}-1)}$,

where $\lambda_{\max }$ is maximum eigenvalue, $n$ is the number of criteria or count.

Using the pairwise matrix each column of the matrix is added and each sum is then multiplied by the respective weight for the criteria (i.e. criteria weight). The resulting matrix, denoted $C_{v}$ in Table 5 , are added together to produce Lambda-max $\left(\lambda_{\max }\right)$. $C I$ was computed from Eq. 2 by inputting $\lambda_{\max }$ value and the number of criteria $(\mathrm{n}=10)$. Using the resulting $C I$ which was 0.008 , and $R I$ of 1.51 for the ten criteria (from literature compiled for $R I$ 's), the $C R$ obtained for the study was 0.006 . This value is approximately $0 \%$ and well under the (0.1) threshold, implying good confidence in the AHP analysis conducted for the study.

\section{Weighted overlay analysis}

The final stage of the suitability analysis was the aggregation of the factors to produce the final land suitability map. Weighted overlay analysis was performed in ArcGIS considering the standardised criteria and their associated weights (Drobne and Lisec 2009). The weighted overlay spatial analysis tool assesses the suitability index for a pixel by multiplying the suitability score and the weight

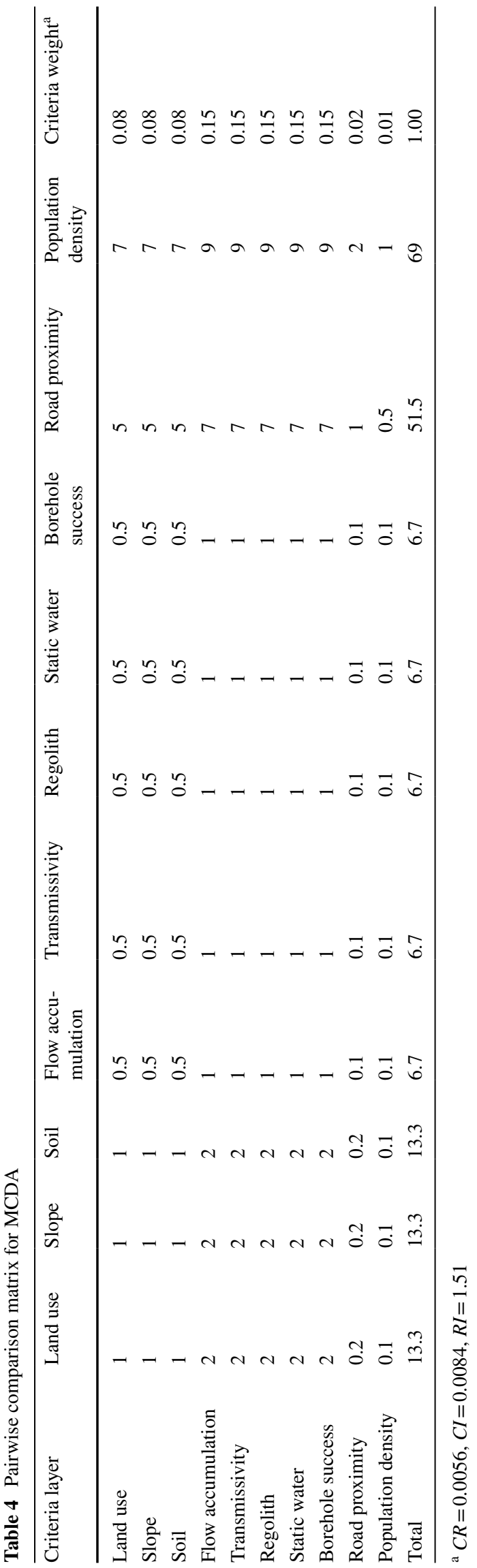


Table 5 Normalised pairwise matrix

\begin{tabular}{|c|c|c|c|c|c|c|c|c|c|c|c|}
\hline Criteria layer & Land use & Slope & Soil & $\begin{array}{l}\text { Flow } \\
\text { accumu- } \\
\text { lation }\end{array}$ & Transmissivity & Regolith & Static water & $\begin{array}{l}\text { Bore- } \\
\text { hole } \\
\text { success }\end{array}$ & Road proximity & $\begin{array}{l}\text { Popula- } \\
\text { tion } \\
\text { density }\end{array}$ & $\mathrm{Cv}$ \\
\hline Land use & 0.07 & 0.07 & 0.07 & 0.07 & 0.07 & 0.07 & 0.07 & 0.07 & 0.10 & 0.10 & 1.06 \\
\hline Slope & 0.07 & 0.07 & 0.07 & 0.07 & 0.07 & 0.07 & 0.07 & 0.07 & 0.10 & 0.10 & 1.06 \\
\hline Soil & 0.07 & 0.07 & 0.07 & 0.07 & 0.07 & 0.07 & 0.07 & 0.07 & 0.10 & 0.10 & 1.06 \\
\hline Flow accumulation & 0.15 & 0.15 & 0.15 & 0.15 & 0.15 & 0.15 & 0.15 & 0.15 & 0.14 & 0.13 & 0.98 \\
\hline Transmissivity & 0.15 & 0.15 & 0.15 & 0.15 & 0.15 & 0.15 & 0.15 & 0.15 & 0.14 & 0.13 & 0.98 \\
\hline Regolith & 0.15 & 0.15 & 0.15 & 0.15 & 0.15 & 0.15 & 0.15 & 0.15 & 0.14 & 0.13 & 0.98 \\
\hline Static water & 0.15 & 0.15 & 0.15 & 0.15 & 0.15 & 0.15 & 0.15 & 0.15 & 0.14 & 0.13 & 0.98 \\
\hline Borehole success & 0.15 & 0.15 & 0.15 & 0.15 & 0.15 & 0.15 & 0.15 & 0.15 & 0.14 & 0.13 & 0.98 \\
\hline Road proximity & 0.01 & 0.01 & 0.01 & 0.02 & 0.02 & 0.02 & 0.02 & 0.02 & 0.02 & 0.03 & 1.03 \\
\hline Population density & 0.01 & 0.01 & 0.01 & 0.02 & 0.02 & 0.02 & 0.02 & 0.02 & 0.01 & 0.01 & 0.96 \\
\hline
\end{tabular}

$\lambda_{\max }=10.076, C I=0.0084$

for the pixel; the summation of the results yields a suitability map using the final formula shown in Eq. 3 (Cengiz and Akbulak 2009; Pramanik 2016; Yalew et al. 2016).

$S=\sum w_{i} x_{i}$,

where $S$ is suitability, $w_{i}$ is weight of factor $i, x_{i}$ is criterion score of factor $i$.

\section{Results}

The outcome presented in Fig. 5 is the weighted suitability analysis of all three criteria presented in Figs. 2, 3 and 4 . From the map, it was determined that about $40 \%$ $\left(29,490 \mathrm{~km}^{2}\right)$ of the study area were within high suitable area $(23 \%)$ and very high suitable areas (18\%), which suggest credible potential for the technology. The moderately suitable class formed $26 \%$ of the entire area $\left(19,026 \mathrm{~km}^{2}\right)$, while the low and very low suitable areas formed $33 \%$ $\left(24,398 \mathrm{~km}^{2}\right)$ of the study area as shown in Table 6 . The study accounted for non-suitable areas (reserved areas)
Fig. 5 Suitability map for ASR in northern Ghana

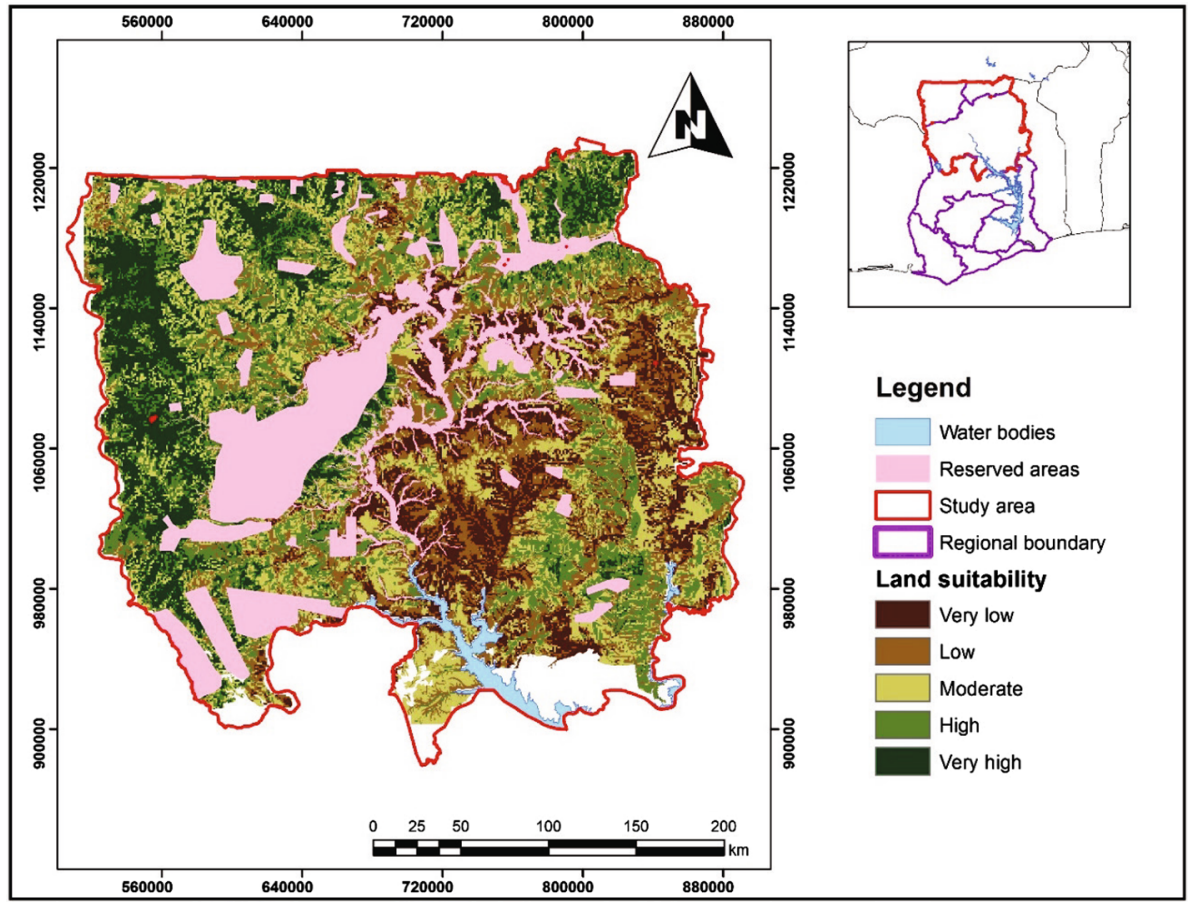


Table 6 Percentage of total area suitable in northern Ghana

\begin{tabular}{llll}
\hline Suitability & Area $\left(\mathrm{km}^{2}\right)$ & $\begin{array}{l}\text { Percent of suit- } \\
\text { able area }(\%)\end{array}$ & $\begin{array}{l}\text { Percent of } \\
\text { Northern Ghana } \\
(\%)\end{array}$ \\
\hline Very low & $10,507.98$ & 14.41 & 11.62 \\
Low & $13,889.87$ & 19.05 & 15.36 \\
Moderate & $19,025.89$ & 26.09 & 21.05 \\
High & $16,647.41$ & 22.83 & 18.42 \\
Very high & $12,842.31$ & 17.61 & 14.21 \\
Total & $72,913.46$ & 100 & 80.66 \\
\hline
\end{tabular}

which include protected sites, floodplains and other development sites, which together formed $\sim 19 \%\left(17,487 \mathrm{~km}^{2}\right)$ of the entire study area which was approximately $90,400 \mathrm{~km}^{2}$. In relation with this total area of northern Ghana, just over $50 \%$ of the area fall within the moderate and very high suitability class and $\sim 27 \%$ within very low and low class.

\section{Discussion}

Innovative systems like ASR can enhance water efficiency, giving farmers economic benefits and at the same time reducing environmental burdens like flood hazard (FAO 2012; Biplab 2013; Levidow et al. 2014). For example, one Bhungroo, an ASR practice implemented in India, is said to be able to free 2 ha of waterlogged land and irrigate around 8-12 ha (Biplab 2013; CA 2015). This could have positive impact on poverty reduction in farming communities given the net income of $\$ 5000$ to $\$ 10,000$ for one Bhungroo technology supporting 8 ha of farmlands for atleast five farming family and has an estimated investment of \$10,000 (Biplab 2013; Naireeta Services 2015). Also, ASR is practiced in the coastal dunes in the Netherlands for domestic water supply (Stuyfzand and Doomen 2004), and elsewhere in Australia ASR has been for irrigation purposes (Gerges et al. 2002; Murray 2008). Although there are challenges to the wider use of such systems, it believed that proper siting and effective management of ASR can help reduce them, including potential contamination to groundwater (EPA 1999; Jurgens et al. 2008).

The study shows that a sizeable area in northern Ghana is potentially suitable for ASR. The most suitable areas are found in the UER and UWR, whereas the NR mainly underlain by Voltaian rocks has limited groundwater potential (HAP 2011; Forkour et al. 2013), and therefore the map showed low suitability. The results support the call for greater investments in AWM particularly groundwater storage systems which are more resilient to the high temperatures in the region resulting in high water losses (Evans et al. 2012; Giordano et al. 2012). Moreover, innovative water lifting systems such as motor and solar pumps, and application tools such as sprinkler and drip irrigation systems can improve yields while minimizing the water losses, compared to the labour intensive and inefficient traditional technologies (FAO 2001; Namara et al. 2011).

In assessing the preference of the criteria, the information about the geology and groundwater potential have relatively high accuracy and very comprehensive (Forkuor et al. 2013); thus, the weight attributed to these components was relatively high. The ranking and weighting of the criteria was based on expert knowledge and the significantly high weight $\sim 58 \%$ for the subsurface criteria means that such characteristics were largely influential in the overall outcome. Notwithstanding, it is worth re-emphasizing the socio-economic influences for the successful implementation of ASR. Acceptability of the technology and high community participation are vital to ensuring the maintenance and sustainability of the innovative systems (Owusu et al. 2017). Moreover, using GIS and remote sensing approach alone to undertake this study is not complete, and therefore field validation will be necessary to make final decision.

\section{Conclusion and recommendation}

The study has provided useful insights into the assessment of suitable sites for installing ASR in northern Ghana. The study primarily employed key biophysical and socioeconomic factors in the assessment. Overall, the analysis has presented substantial areas that can be explored for the implementation of ASR in northern Ghana. The total extent of suitable sites, from moderate to very high, which was $66 \%\left(48,516 \mathrm{~km}^{2}\right)$ is an indication of a majority of the study area and a clear investment option for farmers and policy makers to explore.

Based on the findings there is potential for scaling up the study in the agro-ecological zones of the country, and the wider SSA region where the scheme is applicable. In particular, issues with access to irrigation water and flooding of farmlands can be best managed by adapting these AWM technologies across the region. Such AWM interventions could complement existing practices such as flood recession agriculture to promote dry season farming and improve food security in the region by helping smallholder farmers grow multiple crops per year beyond the rainy season.

Whilst this study provides useful information to guide the implementation of ASR, readers are advised to use the findings with caution due to several limitations in the study approach. The greater challenge faced with the study has to do with the overall quality of the data inputs, which generally were very low resolution. Improved data quality is recommended for future work. 
Acknowledgements This study was part of the Securing Water for Improved Seed and High-Value Vegetable Production in Floodprone areas of Northern Ghana (SecureWater) project funded by the USAID-The Feed the Future Ghana Agriculture Technology Transfer led by IFDC. The BIT was introduced into Ghana in 2015 by Conservation Alliance in collaboration with Naireeta Services (http://www. naireetaservices.com) from India and funded by the CGIAR Research Program on Water, Land and Ecosystems.

Open Access This article is distributed under the terms of the Creative Commons Attribution 4.0 International License (http://creativecommons.org/licenses/by/4.0/), which permits unrestricted use, distribution, and reproduction in any medium, provided you give appropriate credit to the original author(s) and the source, provide a link to the Creative Commons license, and indicate if changes were made.

\section{References}

Balana B, Mul M, Williams TO, Ghansah B, Gyamfuah-Owusu A, Amarnath G (2015) Analysis of historical flood inundation and recession patterns; implications for flood recession agriculture in Northern Ghana. IWMI-IFRI project report, 30 September 2015. Accra, Ghana

Balk DL, Deichmann U, Yetman G, Pozzi F, Hay SI, Nelson A (2006) Determining global population distribution: methods, applications and data. Adv Parasitol 62:119-156

Bandyopadhyay S, Jaiswal RK, Hegde VS, Jayaraman V (2009) Assessment of land suitability potentials for agriculture using a remote sensing and GIS based approach. Int J Remote Sens 30(4):879-895

Bear J (2012) Hydraulics of groundwater. Dover Publication, New York

Biplab KP (2013) Soil water rejuvenation, desertification control and agro productivity augmentation: field experience through Innovation. https://waterlandandecosystems.wikispaces.com/file/view/ Bhungroo.pdf. Accessed 10 Apr 2016

Bouwer H (2002) Artificial recharge of groundwater: hydrogeology and engineering. Hydrogeol J 10:121-142

Bradd JM, Milne-Home WA, Gates G (1997) Overview of factors leading to dryland salinity and its potential hazard in New South Wales, Australia. Hydrogeol J 5(1):51-67

Bunsen J, Rathod R (2016) Pipe assisted underground taming of surface floods: the experience with Holiyas in north Gujarat. IWMITata Water Policy Research Highlight, 2. 8p

CA (2015) Overview of Bhungroo. Conservation Alliance, Accra. http://conservealliance.org/overview-of-bhungroo/. Accessed 10 Apr 2016

Cengiz T, Akbulak C (2009) Application of analytical hierarchy process and geographic information systems in land-use suitability evaluation: a case study of Dümrek village (Çanakkale, Turkey). Int J Sustain Dev World 16:286-294

CWSA (2010) Community water and sanitation agency standards and guidelines, 2010 edn. Ministry of Water Resources, Works and Housing, Ghana (Unpublished)

Dapaah-Siakwan S, Gyau-Boakye P (2000) Hydrogeologic framework and borehole yields in Ghana. Hydrogeol J 8(4):405-416

De Smith MJ, Goodchild MF, Longley PA (2015) Geospatial analysis, 5th edn. http://www.spatialanalysisonline.com/ HTML/?classification_and_clustering.htm. Accessed 19 Sept 2016

Diao X (2010) Economic importance of agriculture for sustainable development and poverty reduction: findings from a case study of Ghana. In: Global forum on agriculture, policies for agricultural development, poverty reduction and food security. OECD, Paris
Drobne S, Lisec A (2009) Multi-attribute decision analysis in GIS: weighted linear combination and ordered weighted averaging. Informatica 33:459-474

Edwards EC, Harter T, Fogg GE, Washburn B, Hamad H (2016) Assessing the effectiveness of drywells as tools for stormwater management and aquifer recharge and their groundwater contamination potential. J Hydrol 539:539-553

EPA (1999) The class V underground injection control study. Volume 3: storm water drainage wells. In: Office of ground water and drinking water. USA EPA, Washington, DC

Evans AEV, Giordano M, Clayton T (eds) (2012) Investing in agricultural water management to benefit smallholder farmers in West Bengal, India. AgWater Solutions Project country synthesis report. International Water Management Institute (IWMI), Colombo, working Paper 148

FAO (2001) Irrigation water management: irrigation methods, Training manual No. 5. ftp://ftp.fao.org/agl/aglw/fwm/Manual5.pdf. Accessed 1 May 2016

FAO (2012) FAO irrigation and drainage Paper 66: crop yield response to water. http://www.fao.org/nr/water/infores.html. Accessed 1 May 2016

FAO. IIASA (International Institute for Applied Systems Analysis), ISRIC (ISRIC-World Soil Information), ISS-CAS (Institute of Soil Science, Chinese Academy of Sciences), JRC (Joint Research Centre, European Commission) (2012) Harmonized world soil database (version 1.2). Rome, Italy: Food and Agriculture Organization of the United Nations (FAO); Laxenburg, Austria: International Institute for Applied Systems Analysis (IIASA). http:// www.fao.org/soils-portal/soil-survey/soil-maps-and-databases/ harmonized-world-soil-database-v12/en/. Accessed 17 Nov 2015

Forkuor G, Pavelic P, Asare E, Obuobie E (2013) Modelling potential areas of groundwater development for agriculture in northern Ghana using GIS/RS. Hydrol Sci J 58(2):437-451

Gerges NZ, Dillon PJ, Sibenaler XP, Martin RP, Pavelic P, Howles SR, Dennis K (2002) South Australian experience in aquifer storage and recovery. In: Dillon PJ (ed) Management of aquifer recharge for sustainability. A.A. Balkema, Rotterdam, pp 453-458

GGS (2009) Geological Map of Ghana-Scale 1:1 000 000. Published and edited the Ghana Geological Survey Department (Accra, Republic of Ghana) in cooperation with the Bundesanstalt für Geowissenschaften und Rohstoffe (Hannover, Federal Republic of Germany)

Giordano M, de Fraiture C, Weight E, van der Bliek J (2012) Water for wealth and food security: supporting farmer-driven investments in agricultural water management. Synthesis report of the AgWater Solutions Project, IWMI

Google Earth (2015) Map of Ghana. https://www.google.com.gh/ maps/@9.7466735,-0.9011178,7.96z. Accessed 15 Apr 2016

Gumma MK, Thenkabail PS, Hedito F, Nelson A, Dheeravath V, Busia D, Rala A (2011) Mapping irrigated areas of Ghana using fusion of $30 \mathrm{~m}$ and $250 \mathrm{~m}$ resolution remote-sensing data. Remote Sens $3(4): 816-835$

HAP (2011) Hydrogeological Assessment Project of the Northern Regions of Ghana. Final Technical Report (ISBN Ref: 978-2-89146-708-7\$4)

Hofkes EH, Visscher JT (1986) Artificial groundwater recharge for water supply of medium-size communities in developing countries. International Reference Centre for Community Water Supply and Sanitation, The Hague

ISSER (2008) The state of the Ghanaian economy in 2008. Institute of Statistical, Social and Economic Research (ISSER), Accra

Jenson SK, Domingue JO (1988) Extracting topographic structure from digital elevation data for geographic information system analysis. Photogramm Eng Remote Sens 54(11):1593-1600

Jurgens BC, Burow KR, Dalgish BA, Shelton JL (2008) Hydrogeology, water chemistry, and factors affecting the transport of 
contaminants in the zone of contribution of a public supply well in Modesto, eastern San Joaquin Valley, California. USGS Scientific Investigations Report 2008-5156

Lee GKL, Chan EHW (2008) The analytic hierarchy process (AHP) approach for assessment of urban renewal proposals. Soc Indic Res 89(1):55-168

Levidow L, Zaccaria D, Maia R, Vivas E, Todorovic M, Scardigno A (2014) Improving water-efficient irrigation: prospects and difficulties of innovative practices. Agric Water Manage 146:84-94

LP DAAC (2016) Land Processes Distributed Active Archive Center DAAC USGS Earth Resource Observation and Science (EROS) Center. https://lpdaac.usgs.gov/citing_our_data. Accessed 15 Nov 2015

McCartney M, Smakhtin V (2010) Water storage in an era of climate change: addressing the challenge of increasing rainfall variability. Blue paper. International Water Management Institute (IWMI), Colombo

Motuma M, Suryabhagavan KV, Balakrishnan M (2016) Land suitability analysis for wheat and sorghum crops in Wogdie District, South Wollo, Ethiopia, using geospatial tools. Appl Geomat 8(1):57-66

Mul M, Obuobie E, Appoh R, Kankam-Yeboah K, Bekoe-Obeng E, Amisigo B, Logah FY, Ghansah B, McCartney M (2015) Water resources assessment of the Volta River Basin. International Water Management Institute (IWMI), Colombo. doi: 10.5337/2015.220 (Working Paper 166)

Murray R (2008) The intentional banking and treating of water in aquifers, Lecture notes prepared for the Department of Water Affairs and Forestry. Pretoria

Murray EC, Tredoux G (1998) Artificial recharge: a technology for sustainable water resource development: final report to the water research commission. WRC, Pretoria

Naireeta Services (2015) Bhungroo. http://www.naireetaservices.com. Accessed 15 Aug 2016

Namara R, Horowitz L, Nyamadi B, Barry B (2011) Irrigation development in Ghana: past experiences, emerging opportunities, and future directions. Ghana Strategy Support Program, working paper no. 0027

Namara R, Hope L, Owusu SE, Owusu D (2014) Adoption patterns and constraints pertaining to small-scale water lifting technologies in Ghana. Agric Water Manage 131:194-203

Nobre AD, Cuartas LA, Momo MR, Severo DL, Pinheiro A, Nobre CA (2016) HAND contour: a new proxy predictor of inundation extent. Hydrol Process 30(2):32-333

Obuobie E (2008) Estimation of groundwater recharge in the context of future climate change in the White Volta River Basin. Ecology series $62,153 \mathrm{p}$
Obuobie E, Barry B (2012) Chap. 4, Ghana. In: Pavelic P, Giordano M, Keraita B, Ramesh V, Rao T (eds) Groundwater availability and use in Sub-Sahara Africa: A review of 15 countries. International Water Management Institute (IWMI), Colombo

Owusu S, Cofie OO, Osei-Owusu PK, Awotwe-Pratt V, Mul ML (2017) Adapting aquifer storage and recovery technology to the floodprone areas of northern Ghana for dry-season irrigation. International Water Management Institute (IWMI), Colombo, 35 p. doi: 10.5337/2017.214 (IWMI Working Paper 176)

Pramanik MK (2016) Site suitability analysis for agricultural land use of Darjeeling district using AHP and GIS techniques. Model Earth Syst Environ 2(2): 1-22

Pyne RDG (1995) Groundwater recharge and wells: a guide to aquifer storage recovery. CRC Press, Boca Raton

Saaty TL (1980) The analytic hierarchy process: planning, priority setting, resource allocation. McGraw-Hill International Book Co, New York

Saaty TL (1988) What is the analytic hierarchy process? Springer, Berlin

Saaty TL (2008) Decision making with the analytic hierarchy process. Int J Serv Sci 1(1):83-98

SADA (2006) Savannah accelerated development authority: maps. http://sadagh.org/index.php/maps. Accessed 12 Apr 2016

Sasson A (2012) Food security for Africa: an urgent global challenge. Agr Food Secur 1:1-16

Singh A (2016) Managing the water resources problems of irrigated agriculture through geospatial techniques: an overview. Agric Water Manage 174:2-10

Singh A, Krause P, Panda SN, Flugel WA (2010) Rising water table: a threat to sustainable agriculture in an irrigated semi-arid region of Haryana, India. Agric Water Manage 97(10):1443-1451

Stuyfzand PJ, Doomen A (2004) The Dutch experience with MARS (managed aquifer recharge and storage): a review of facilities, techniques and tools (Version 1). An NWP/PMC Groundwater Publication, KIWA Partners voor Water, The Netherlands

UNDP (2009) Recovery programming support for northern Ghana. Project document. http://www.undp.org/content/dam/undp/ documents/projects/GHA/00057556_Ghana\%20-\%20Recovery \%20Project\%20in\%20Northern\%20Ghana_prodoc_Final_ April21.2009.doc. Accessed 16 Oct 2015

UNFCC (2014) Momentum or change 2014 Lighthouse activities. http://newsroom.unfccc.int/media/155618/brochure-2014-lighthouse-activities-low-res.pdf. Accessed 1 Apr 2015

Yalew SG, van Griensven A, Mul ML, van der Zaag P (2016) Land suitability analysis for agriculture in the Abbay basin using remote sensing, GIS and AHP techniques. Model Earth Syst Environ 2:101. doi:10.1007/s40808-016-0167-x 